\title{
Modern pollen-vegetation relationships in the Drakensberg Mountains, South Africa
}

\author{
Trevor R. Hill \& Jemma M. Finch \\ Discipline of Geography, School of Agricultural, Earth and Environmental \\ Sciences, University of KwaZulu-Natal, Pietermaritzburg, South Africa
}

\begin{abstract}
Contemporary pollen rain studies are conducted to determine pollen-vegetation relationships and develop modern analogues to facilitate palaeoreconstruction from fossil pollen assemblages. In this study, a two year modern pollen sampling campaign was conducted for eleven vegetation communities across a range of altitudes in the Drakensberg Mountains, South Africa. The aim was to compare pollen assemblage composition, diversity, and influx between vegetation communities, and investigate representivity of taxa. Despite a high degree of within and between community homogeneity, characteristic pollen taxa are suggested as indicative of particular communities. We highlight over- and under-representation of certain taxa within the vegetation communities and list 'palynologically silent' taxa - those that appear in the vegetation but are absent from the modern pollen spectra. From the resultant modern pollen assemblages, it is not possible to distinguish the grassland types, although the possibility does exist for the forest, shrubland and wetland communities. Arboreal Celtis and Podocarpus pollen types are diagnostic for the Afrotemperate forest community, and Leucosidea sericea for the shrubland community which it dominates. We suggest that modern pollen analogues are feasible for the non-grassland Drakensberg communities and echo the sentiments of others that modern pollen rain-vegetation dynamics are a prerequisite to accurately constrain interpretation of fossil pollen spectra.
\end{abstract}

\subsection{INTRODUCTION}

The modern pollen-vegetation relationship underpins vegetation reconstructions from fossil pollen data, and yet foundational studies exploring this relationship are often lacking, particularly in the tropics and subtropics. Outside of temperate zones, traditional assumptions surrounding pollen representivity of anemophilous and zoophilous taxa have been challenged, and require further investigation to understand complex bias introduced by variable pollen production and dispersal (Watrin et al. 2007). Detailed studies of local pollen and parent vegetation can be used to determine pollen taphonomy, and explore representivity within the pollen rain. Few such small-scale studies exist for the African tropics and subtropics (e.g. Elenga et al. 2000; HengaBotsikabobe et al. 2020; Julier et al. 2018; Marchant and Taylor 2000; Schüler et al. 2014), thereby limiting palaeoecological inferences and attempts to model vegetation from pollen data.

Southern Africa has an established tradition of palynological research, dating back to the pioneering efforts of van Zinderen Bakker (1950, 1951). Early palynologists often incorporated a few surface pollen spectra to support fossil pollen records (e.g. Cooremans 1989; Scott 1982a, b, 1989; Scott and Cooremans 1992; Scott et al. 1992), however, relatively few dedicated studies, particularly those with a temporal component, exist (Hill 1995). A recent modelling synthesis of modern pollen data from southern Africa pulled together a dataset of mostly surface soil samples 
from 211 sites across the subregion (Sobol et al. 2019), showing strong bias towards savanna $(n=67)$ and grassland $(n=53)$ relative to the other seven biomes. More detailed local studies, which employ passive pollen traps to calibrate modern-pollen vegetation relationships, include those from the Winterberg (Meadows and Meadows 1988), Nuweveldberg (Sugden and Meadows 1989), and Cederberg (Meadows and Sugden 1990; 1991a;b), all in the winter rainfall zone. In the absence of such detailed contemporary pollen studies, Meadows (1989, p. 160) commented that the reconstruction of palaeovegetation communities is 'largely guesswork'. Recent advances in the field include modelled estimates of relevant source area of pollen and relative pollen productivity undertaken in the Kruger National Park (Duffin and Bunting 2008) and Drakensberg Mountains (Duthie et al., this volume). Despite these efforts, modern pollen-vegetation relationships in the subregion 'remain poorly resolved relative to other parts of the world' (Meadows 2015, p. 4).

In this paper, we present the results of a highly detailed modern pollen rain survey from the KwaZulu-Natal Drakensberg, comprising data from eleven vegetation communities and corresponding surface soil samples, in addition to seasonal pollen trap data spanning a two year period. The aim is to characterise the modern pollen rain produced by each vegetation community by (i) comparing pollen spectra, diversity and influx across the different vegetation communities; and (ii) determining which taxa are under- and overrepresented in the pollen assemblage. The research was carried out in the Cathedral Peak area of the northern KwaZulu-Natal Drakensberg Mountains $\left(29^{\circ} 00^{\prime} \mathrm{S}, 29^{\circ} 15^{\prime} \mathrm{E}\right.$; Figure 1$)$, in South Africa's summer rainfall zone. This mountainous environment presents the opportunity to study a range of vegetation communities within a confined region due to the altitudinal gradient, ranging from open grassland to ericaceous scrub, closed woodland and forest. The broader Maloti-Drakensberg region is recognised as having the preservation potential for late Quaternary palynological studies due to the availability of high altitude polliniferous deposits (e.g. Fitchett et al. 2016; 2017; Lodder et al. 2018; Neumann et al. 2014; Norström et al. 2009; van Zinderen Bakker 1955).

\subsection{MATERIALS AND METHODS}

Sampling design was based on eleven vegetation communities from three altitudinal zones (Table 1; Figure 2), viz. the montane (1280-1829 m asl), subalpine (1830-2865 $\mathrm{m}$ asl) and the alpine belts (2866-3353 m asl) (Killick 1963). Selected communities represented either (i) the dominant community within a vegetation belt; (ii) communities which follow a particular successional pathway; or (iii) communities that characterise a distinct topographic or geomorphological feature within the altitudinal vegetation belt. Killick (1963) and Hill (1996) describe the species composition and abundance within each of these vegetation communities in detail.

Vegetation surveys were undertaken within each of the communities and species present and percentage aerial cover were recorded (Table 1). The percentage aerial cover was deemed more appropriate than the more conventional basal cover (Bradshaw 1981) as aerial cover is an estimate of the dominance of a particular species within the community. As the pollen is produced from the upper aerial part of the plant it was presumed that this measure would provide a better representation of the amount of pollen produced. Percentage aerial cover was measured as the proportion of the ground occupied by perpendicular projections onto it of the aerial parts of the individuals of a species under consideration (Kershaw and Looney 1985).

Meadows (1989) advocates for the collection of surface samples, and corresponding trap data, from as many plant communities as possible. Here, modern pollen rain was sampled passively using a modified version of the Oldfield pollen trap (Flenley 1973), which is easy to construct, transport, install and recollect in an inaccessible mountainous environment. Pollen traps were randomly installed within each community at a height of $1 \mathrm{~m}$ above the ground. The number of pollen traps placed in each vegetation community varied between 5-18 based on the 


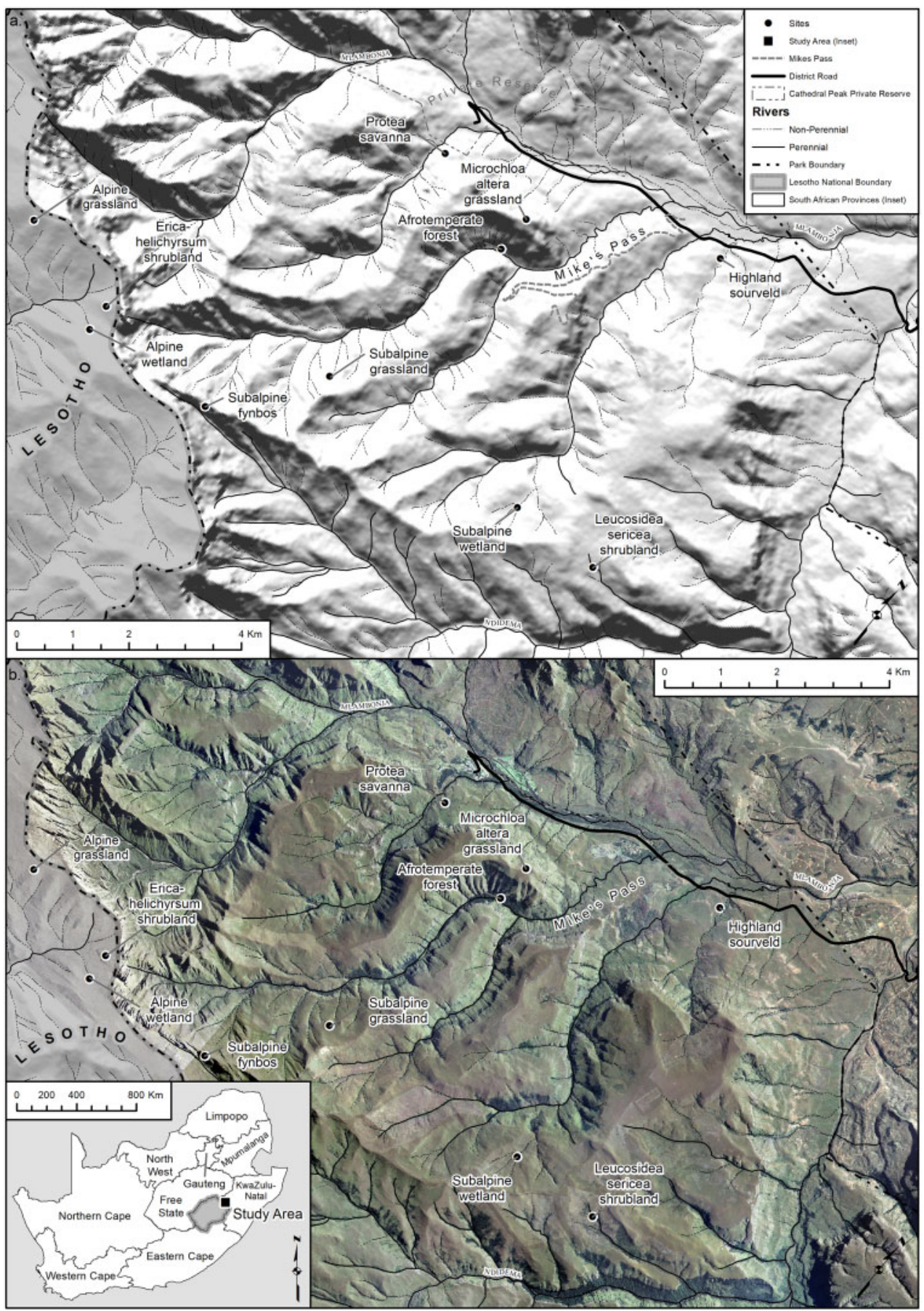

Figure 1. (a) Location map and (b) aerial photograph of the Cathedral Peak area of the KwaZulu-Natal Drakensberg, indicating the position of vegetation communities investigated relative to important topographic features. 
Table 1. Distribution of pollen and vegetation samples among the eleven vegetation communities. Pollen traps were sampled on a seasonal basis across a two-year period, hence total pollen samples exceeds individual samples per community. Alpine communities were sampled using soils, while subalpine and montane communities used pollen traps.

\begin{tabular}{|c|c|c|c|c|c|c|}
\hline $\begin{array}{l}\text { Vegetation } \\
\text { community } \\
\text { (code) }\end{array}$ & $\begin{array}{l}\text { Geographical } \\
\text { position } \\
\text { (GPS) }\end{array}$ & $\begin{array}{l}\text { Elevation } \\
\text { (m asl) }\end{array}$ & $\begin{array}{l}\text { No. } \\
\text { pollen } \\
\text { samples }\end{array}$ & $\begin{array}{l}\text { Total pollen } \\
\text { samples } \\
\text { (all seasons) }\end{array}$ & $\begin{array}{l}\text { No. of } \\
\text { vegetation } \\
\text { quadrats }\end{array}$ & $\begin{array}{l}\text { Quadrat } \\
\text { size }\end{array}$ \\
\hline \multicolumn{7}{|l|}{ Alpine } \\
\hline $\begin{array}{l}\text { Alpine grassland } \\
\text { (AG) }\end{array}$ & $\begin{array}{c}-28.98 \\
29.13\end{array}$ & 3000 & 20 & 20 & 20 & $1 \times 1 \mathrm{~m}$ \\
\hline $\begin{array}{l}\text { Alpine wetland } \\
\text { (AW) }\end{array}$ & $\begin{array}{c}-29.01 \\
29.18\end{array}$ & 2965 & 20 & 20 & 20 & $1 \times 1 \mathrm{~m}$ \\
\hline $\begin{array}{l}\text { Erica Helichrysum } \\
\text { shrubland (EH) }\end{array}$ & $\begin{array}{c}-29.00 \\
29.18\end{array}$ & 3010 & 20 & 20 & 20 & $1 \times 1 \mathrm{~m}$ \\
\hline \multicolumn{7}{|l|}{ Subalpine } \\
\hline $\begin{array}{l}\text { Leucosidea sericea } \\
\text { shrubland (LS) }\end{array}$ & $\begin{array}{c}-28.99 \\
29.26\end{array}$ & 1895 & 10 & 63 & 20 & $10 \times 10 \mathrm{~m}$ \\
\hline $\begin{array}{l}\text { Microchloa altera } \\
\text { grassland (MA) }\end{array}$ & $\begin{array}{c}-28.95 \\
29.22\end{array}$ & 1810 & 5 & 32 & 20 & $1 \times 1 \mathrm{~m}$ \\
\hline $\begin{array}{l}\text { Subalpine } \\
\text { fynbos (SF) }\end{array}$ & $\begin{array}{r}-29.01 \\
29.20\end{array}$ & 2690 & 10 & 37 & 20 & $10 \times 10 \mathrm{~m}$ \\
\hline $\begin{array}{l}\text { Subalpine } \\
\text { grassland (SG) }\end{array}$ & $\begin{array}{c}-28.99 \\
29.21\end{array}$ & 1975 & 25 & 175 & 60 & $1 \times 1 \mathrm{~m}$ \\
\hline $\begin{array}{l}\text { Subalpine } \\
\text { wetland (SW) }\end{array}$ & $\begin{array}{c}-28.99 \\
29.25\end{array}$ & 1890 & 6 & 31 & 25 & $1 \times 1 \mathrm{~m}$ \\
\hline \multicolumn{7}{|l|}{ Montane } \\
\hline $\begin{array}{l}\text { Afrotemperate } \\
\text { forest }(\mathrm{AF})\end{array}$ & $\begin{array}{l}-28.96 \\
29.22\end{array}$ & 1550 & 18 & 125 & 20 & $10 \times 10 \mathrm{~m}$ \\
\hline $\begin{array}{l}\text { Highland } \\
\text { sourveld (HS) }\end{array}$ & $\begin{array}{c}-28.93 \\
29.25\end{array}$ & 1350 & 5 & 32 & 25 & $1 \times 1 \mathrm{~m}$ \\
\hline $\begin{array}{l}\text { Protea } \\
\text { savanna (PS) }\end{array}$ & $\begin{array}{c}-28.95 \\
29.20\end{array}$ & 1545 & 18 & 115 & 20 & $10 \times 10 \mathrm{~m}$ \\
\hline Total & & & 159 & 670 & 270 & \\
\hline
\end{tabular}

size and complexity of the community (Table 1). The traps have proved successful collectors of pollen rain and, in some instances, provide a better reflection of the vegetation community prevailing in the catchment area than surface soil samples (Crowder and Starling 1980; Meadows and Sugden 1991b; Sugden 1990). Twenty surface soil samples were taken randomly from each vegetation community. A sample of approximately $100 \mathrm{~g}$ constituting the top $3-5 \mathrm{~cm}$ of the soil was collected, with overlying organic matter having been first removed. Samples were placed into paper bags, sealed and refrigerated to reduce bacterial and fungal growth, until the necessary laboratory techniques could be carried out (Hicks and Hyvärinen 1986).

Fieldwork was undertaken from June 1988 to June 1990, thereby gaining a full two years of modern pollen rain data. The traps were replaced on a tri-monthly basis until NovemberDecember 1989. A seventh sample of six months duration, December 1989 to June 1990, was collected to compare a six month sample with the usual tri-monthly samples. Two full years of data were not achieved for the subalpine fynbos and subalpine wetland communities (Table 1). 

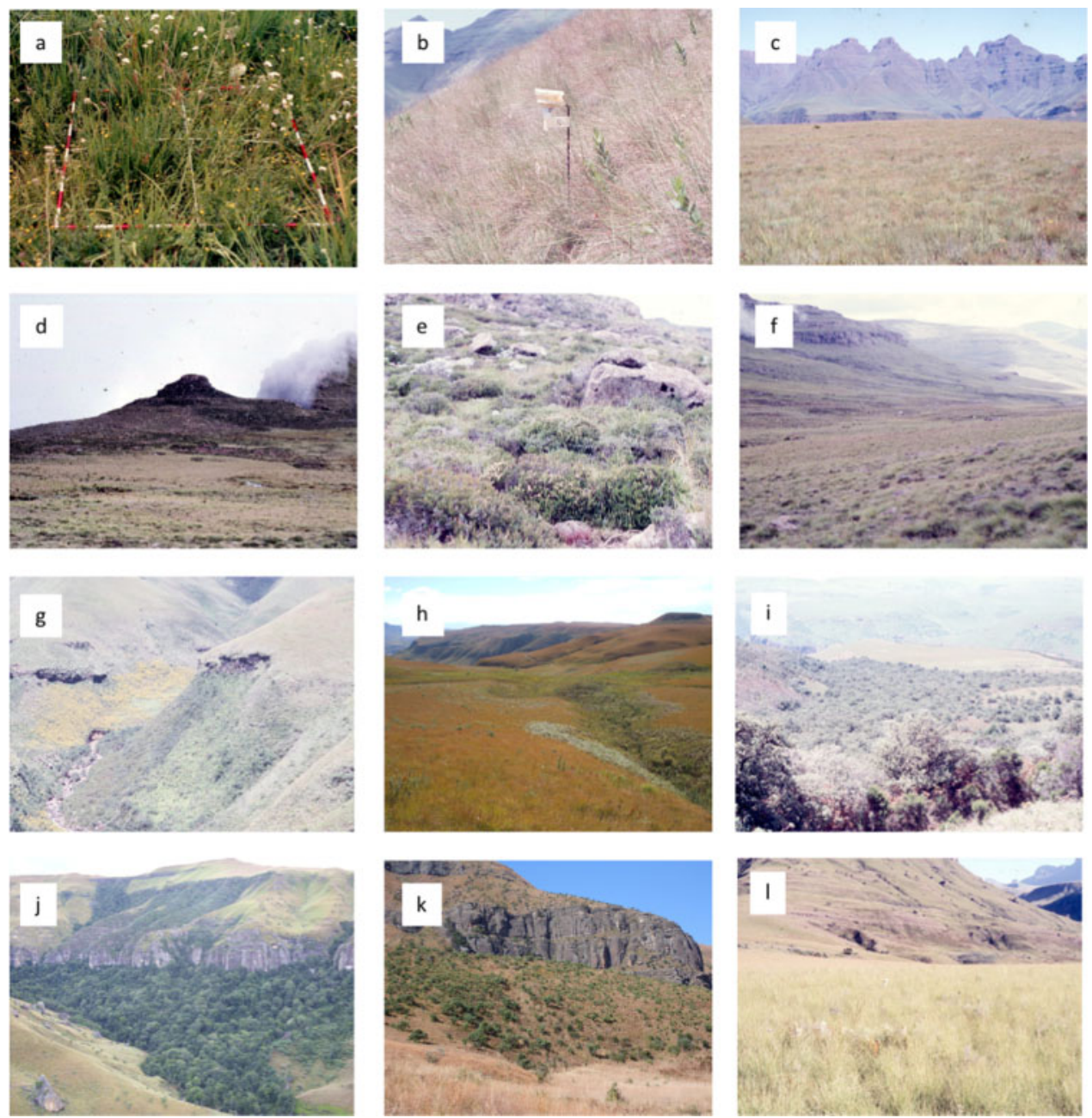

Figure 2. (a) $1 \times 1 \mathrm{~m}$ quadrat used for aerial vegetation survey; (b) passive pollen trap; (c) subalpine grassland; (d) alpine grassland; (e) Erica Helichrysum shrubland; (f) alpine wetland; (g) subalpine fynbos; (h) subalpine wetland; (i) Leucosidea sericea shrubland; (j) Afrotemperate forest; (k) Protea savanna; (1) highland sourveld.

Pollen was extracted from the traps and soil samples using acetolysis (Faegri and Iversen 1989). Identification was achieved using a predominantly local pollen reference collection of c. 700 species (Hill 1992). Absolute counts of $c .500$ on trap samples and c. 1000 on soil samples were performed on pollen grains and spores (hereafter collectively termed 'pollen' for brevity). Pollen influx values were calculated based on sample volume as grains $/ \mathrm{cm}^{2} / 30$ days (Berglund and Ralska-Jasiewiczowa 1986). R-rel values were calculated ( $\mathrm{R}-\mathrm{rel}=\%$ mean abundance in pollen rain/\% aerial cover of vegetation) (Davis 1963; Gosling et al. 2005) for each taxon in each community to understand the representivity of pollen taxa across the landscape. The ShannonWiener Index was calculated for each pollen sample and each vegetation community to determine how well the pollen assemblage captured vegetation diversity. The index ranges from $0-5$, with most values falling between 1.5 and 3.5, and is a comparative index with higher values indicating higher diversity (Barnes et al. 1998). It should be acknowledged that many pollen taxa cannot be 
distinguished below the family level and thus the diversity index was calculated at the taxonomic level of the identified palynomorphs. The multivariate structure of the pollen assemblage data was represented using non-metric multidimensional scaling (nMDS) using the software PRIMER v7 (Clarke and Gorley 2015). The data were 4th root transformed to down weight the dominant species and Bray-Curtis similarity matrix calculated. Vectors of important species were based on Pearsons rank correlation. A pollen diagram showing characteristic taxa for each community was plotted using C2 (Juggins 2007).

\subsection{RESULTS}

From a total of $c .700$ pollen traps deployed over the two year period, 16 were lost or damaged by animals or fire. All 36 traps deployed in the alpine belt over two attempts were stolen, thus surface soil samples were relied upon as a substitute within this vegetation belt. Pollen assemblage count size varied with an average of 1120 grains counted per soil sample in the alpine communities (ranging from 965-1272 grains per sample), and an average of 560 grains counted per trap in the subalpine and montane communities (ranging from 207-3392 grains per sample). A complete list of all pollen taxa recorded together with potential parent vegetation based on vegetation survey data is provided in supplementary information and used to infer likely parent taxa, which are indicated in parentheses (Hill 1992; Table S1).

\subsubsection{Characterisation of vegetation communities by pollen assemblage}

A total of 25 characteristic taxa were designated on the basis of being recorded from at least $80 \%$ of the samples from a vegetation community, and at $>3 \%$ abundance in one sample or more (Table S1). Asteraceae, Cyperaceae, Poaceae and Pteridophyta are ubiquitous and characteristic across all altitudinal zones and vegetation communities, and are therefore deemed to be of limited value as diagnostic taxa.

For pollen trap data, relative abundance data are averaged across the seven time intervals due to a focus on spatial rather than temporal assemblage variability. Spatial variability in the pollen assemblage, both between and within vegetation communities, is depicted according to relative abundance of characteristic taxa, pollen influx, and assemblage diversity (Figure 3ac). Influx values are indicated for all subalpine and montane belt communities together with relative abundance data for each trap (Figure 3b-c). It is worth noting that while some vegetation communities were represented by a high number of samples (up to 25 traps or 20 soil samples), the M. altera grassland and highland sourveld contained only five traps each, which may contribute towards their apparent homogeneity.

\subsubsection{Alpine belt}

The alpine vegetation communities display a relatively high degree of homogeneity within each community, and all three are distinctive for the presence of bryophyte spores which are absent from other altitudinal zones (Figure 3a). Within the alpine grassland the diversity index ranged from 1.2-1.5 with an average of 1.4 (Figure 4), and the most abundant taxa are Poaceae and Cyperaceae. Similar to the alpine grassland, the alpine wetland is dominated by Poaceae and Cyperaceae. The consistent presence of Umbelliferae (Apiaceae) in the pollen assemblage distinguishes the alpine wetland from other communities across the altitudinal range. The alpine wetland diversity ranged from 1.6-2.2 with an average of 1.9 (Figure 4). Distinctive taxa within the Erica Helichrysum shrubland include Ericaceae and Thymelaeaceae. Diversity ranged from 1.1 to 1.9 , with an average of 1.6 (Figure 4). 


\subsubsection{Subalpine belt}

Aside from the subalpine fynbos, the other subalpine communities are relatively homogenous within individual communities.

Leucosidea sericea shrubland - L. sericea shrubland is distinctive for dominant $L$. sericea pollen $(30-60 \%)$, and the presence of Ericaceae. Diversity ranged from 1.2-2, with an average of 1.7. Influx rates varied from 65 to 275 grains $/ \mathrm{cm}^{2} / \mathrm{month}$, with an average of 107 grains $/ \mathrm{cm}^{2} /$ month (Figure $3 b$ ).

Microchloa altera grassland - The M. altera pollen assemblage is fairly uniform, with the main distinction being the low presence of extra-local forest taxa Celtis $(<5 \%)$ and Podocarpus $(<5 \%)$, due to the close proximity of this community to the edge of an Afrotemperate forest patch ( $<300 \mathrm{~m}$ ). In the M. altera grassland, diversity varied from 2-2.1 with an average of 2.1 (Figure 4 ). Influx rates varied from 104 to 239 grains $/ \mathrm{cm}^{2} / \mathrm{month}$, with an average of $145 \mathrm{grains} / \mathrm{cm}^{2} / \mathrm{month}$.

Subalpine fynbos - In the subalpine zone, the subalpine fynbos community displays a high degree of heterogeneity across the community, largely centred around variations in three taxa, viz. Ericaceae, Proteaceae and Scrophulariaceae (Figure 3b). In the subalpine fynbos, diversity ranged from 1.8-2.5 (average 2.3) (Figure 4). Influx rates varied from 101 to 269 grains $/ \mathrm{cm}^{2} / \mathrm{month}$, with an average of 172 grains $/ \mathrm{cm}^{2} /$ month.

Subalpine grassland - The subalpine grassland and M. altera grassland communities are similar, with the exception of forest taxa presence in the latter. In the subalpine grassland, pollen assemblage diversity ranged from 1.6 to 1.8 , with an average of 1.7 (Figure 4). Influx rates varied from 118 to 409 grains $/ \mathrm{cm}^{2} /$ month, with an average of 199 grains $/ \mathrm{cm}^{2} / \mathrm{month}$ (Figure $3 \mathrm{~b}$ ).

Subalpine wetland-As with subalpine grassland communities, the subalpine wetland pollen assemblage is Poaceae-Asteraceae dominated, and includes relatively high Cyperaceae (10-15\%) and Pteridophyta (10-20\%) frequencies. Diversity ranged from 1.8-2.1 (average 1.9) (Figure 4). Influx rates varied from 140 to 274 grains $/ \mathrm{cm}^{2} /$ month, with an average of 198 grains $/ \mathrm{cm}^{2} / \mathrm{month}$.

\subsubsection{Montane belt}

Afrotemperate forest - In the montane belt, there is a high degree of heterogeneity across the Afrotemperate forest community, particularly in the relative dominance of Podocarpus (5-40\%) and Celtis (5-40\%) (Figure 3c). This community displays a relatively strong arboreal pollen assemblage, muting the ubiquitous Asteraceae/Poaceae signal evident in other communities. The Afrotemperate forest diversity varied from 1.8-2.5 (average 2.1) (Figure 4). Pollen influx was highly variable, ranging from 111 to 493 grains $/ \mathrm{cm}^{2} / \mathrm{month}$, with an average of 264 grains/ $\mathrm{cm}^{2} /$ month (Figure $3 \mathrm{c}$ ).

Protea savanna - The Protea savanna is distinctive for its high level of Proteaceae pollen (15-50\%). Pollen assemblage diversity varied from 1.7 to 2 with an average of 1.9 (Figure 4). Influx rates varied from 68 to 275 grains $/ \mathrm{cm}^{2} /$ month, with an average of 129 grains $/ \mathrm{cm}^{2} / \mathrm{month}$.

Highland sourveld - The highland sourveld is similar to the subalpine grassland community, with no distinctive characteristic taxa evident from the modern pollen data. In the highland sourveld, diversity varied between 1.5-1.6, with an average of 1.5 (Figure 4). Pollen influx varied from 94 to 185 grains $/ \mathrm{cm}^{2} / \mathrm{month}$ (average 127 grains $/ \mathrm{cm}^{2} / \mathrm{month}$ ) (Figure 3c).

\subsubsection{Representivity of the pollen assemblage}

Where characteristic pollen taxa are recorded together with the corresponding parent vegetation type in the surrounding community, the relative frequencies of pollen and vegetation can be directly compared to provide an indication of the degree of correspondence between pollen rain and parent vegetation composition (Figure S1). The R-rel value can be used as an indicator of representivity, with values $<1$ indicating underrepresentation and values $>1$ indicating overrepresentation (Figure 5). Furthermore, we can plot pollen abundance against vegetation 
(a) Alpine vegetation belt

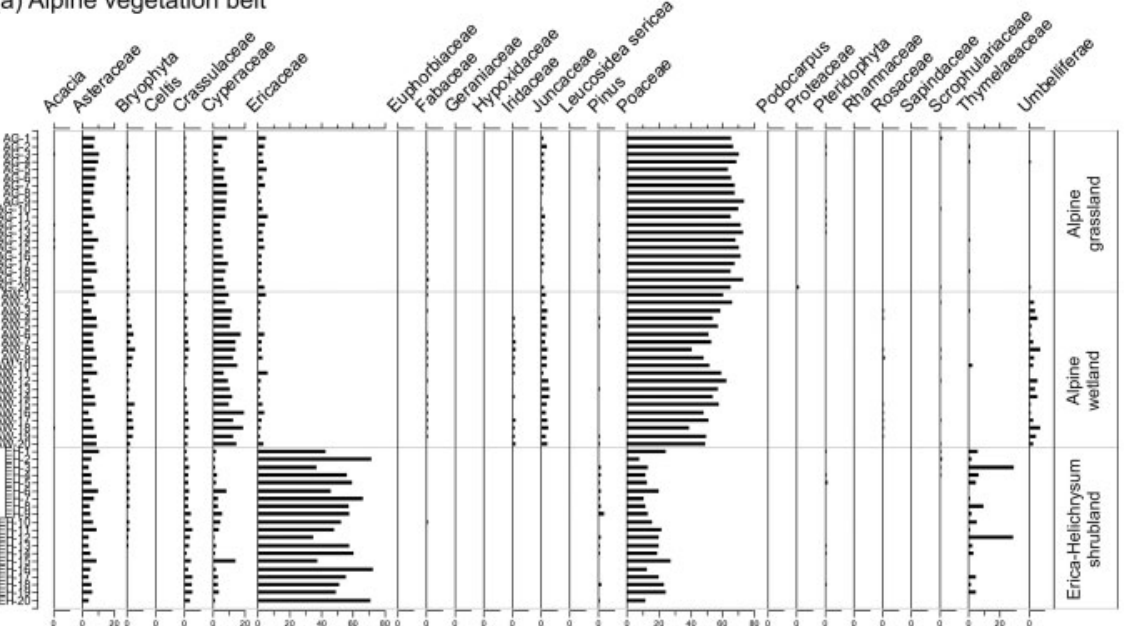

(b) Subalpine vegetation belt

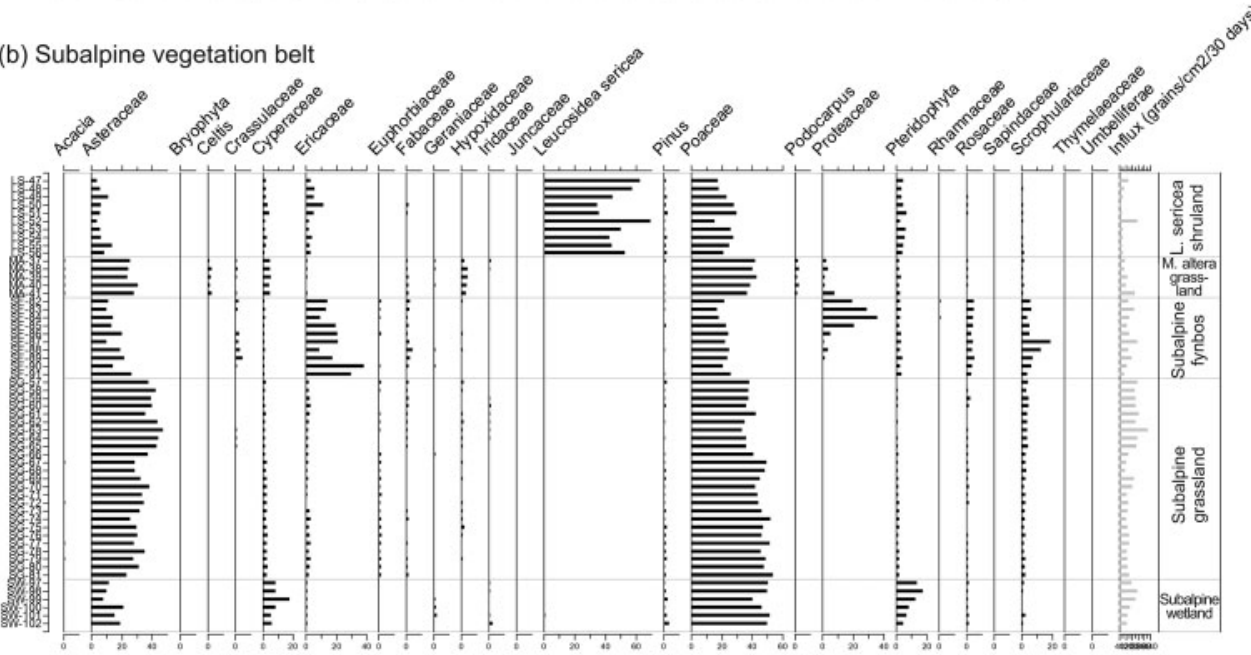

(c) Montane vegetation belt

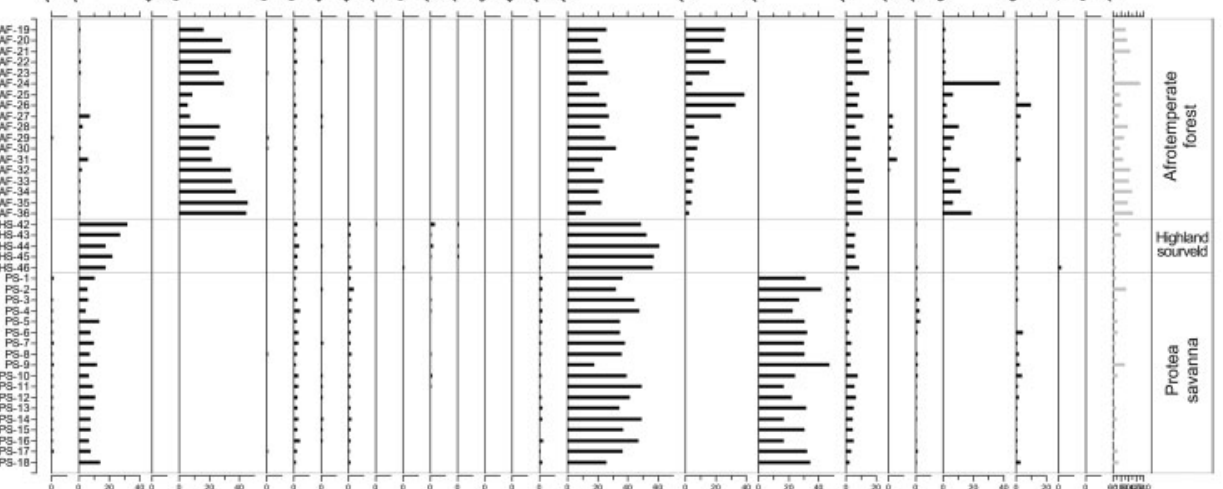

Figure 3. Pollen diagram showing pollen assemblages with samples grouped by vegetation community in the (a) alpine belt; (b) subalpine belt; and (c) montane belt, along with total influx values for each trap. For the three alpine vegetation communities, pollen data are derived from surface soil samples rather than traps. 


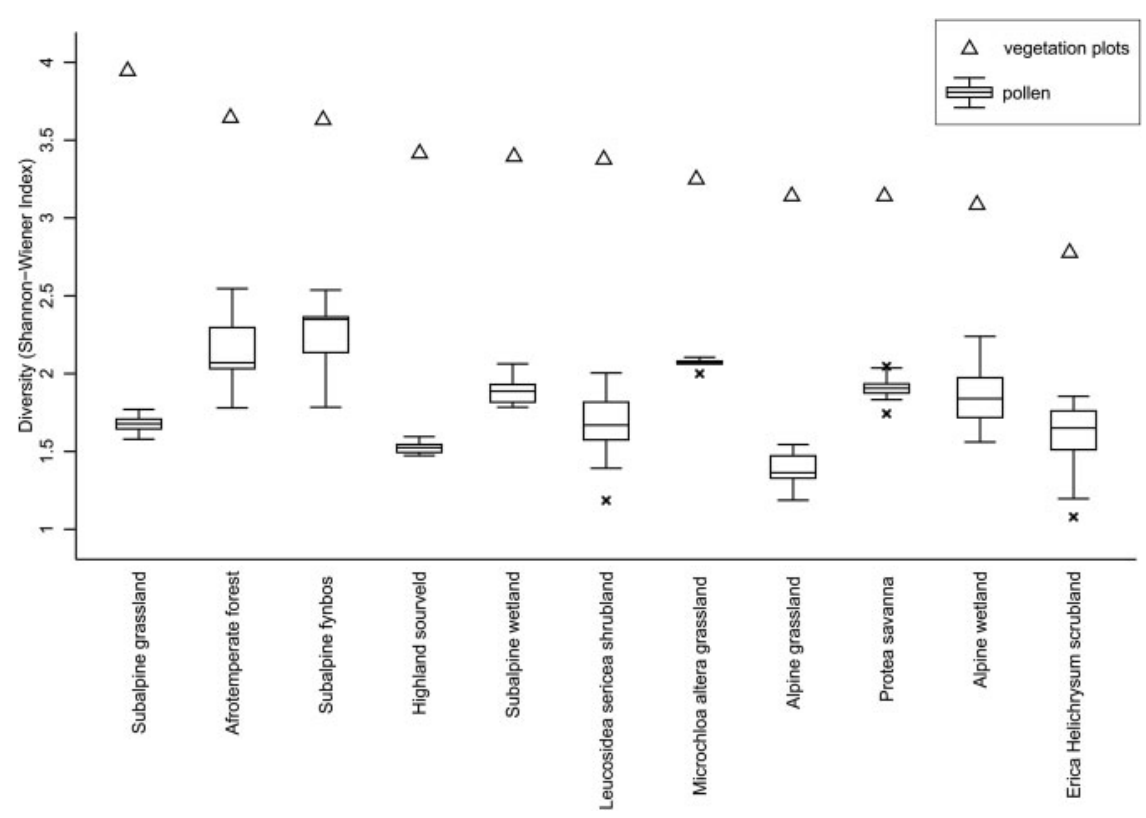

Figure 4. Boxplot showing diversity (Shannon-Wiener Index) of the pollen assemblages across each vegetation community. Communities are ranked according to species level diversity of the plots (triangle symbols), in order of decreasing diversity. For alpine grassland, alpine wetland, and Erica Helichrysum shrubland, pollen data are derived from surface soil samples rather than traps.

abundance using a R-rel reference line of 1 as a guide to over- and underrepresentation (Figure S2). Results show that for many taxa the representivity of the pollen type varies between vegetation communities.

In both the alpine and subalpine wetland communities, Cyperaceae is notably underrepresented, with a R-rel of 0.2-0.4 (Figure 5), whilst Poaceae is overrepresented. Some dominant taxa, such as Poaceae, are highly variable in their degree of representivity between communities (Figure S2). In general, Asteraceae appear to be overrepresented with the exception of the Erica Helichrysum shrubland where they are notably underrepresented $(\mathrm{R}-\mathrm{rel}=0.2)$ (Figure 5, S2). Based on high R-rel values exceeding 2 (Figure 5), Scrophulariaceae pollen appears to be highly overrepresented in all vegetation communities where it is recorded, with the exception of the L. sericea shrubland and subalpine wetland (Figure 5). Similarly, Crassulaceae are overrepresented in the alpine wetland and Erica Helichrysum communities (Figure 5).

Ericaceae pollen appears to be fairly representative of the vegetation cover in the subalpine fynbos and L. sericea shrubland, with a R-rel of 1.1-1.2 (Figure 5). However, in the Erica Helichrysum shrubland Ericaceae pollen is overrepresented with a R-rel of 1.7 (Figures 5, S2). L. sericea pollen abundance mirrors that of the parent vegetation in the L. sericea shrubland community, with a R-rel of c. 1.1 (Figures 5, S2).

When comparing aerial vegetation cover of Celtis with the pollen assemblage in the Afrotemperate forest, Celtis pollen is found to be overrepresented with a R-rel value of 1.7 (Figures 5, S2). Podocarpus pollen is underrepresented relative to the vegetation cover in the Afrotemperate forest, with a R-rel of 0.4 (Figures 5, S2). In the Protea savanna, Proteaceae pollen is underrepresented relative to the surrounding vegetation, with a R-rel of 0.6 (Figures 5, S2).

In the alpine grassland, Brassicaceae (Heliophila) pollen was absent, despite the parent taxon was recorded in the surrounding vegetation. These 'palynologically silent' taxa are 

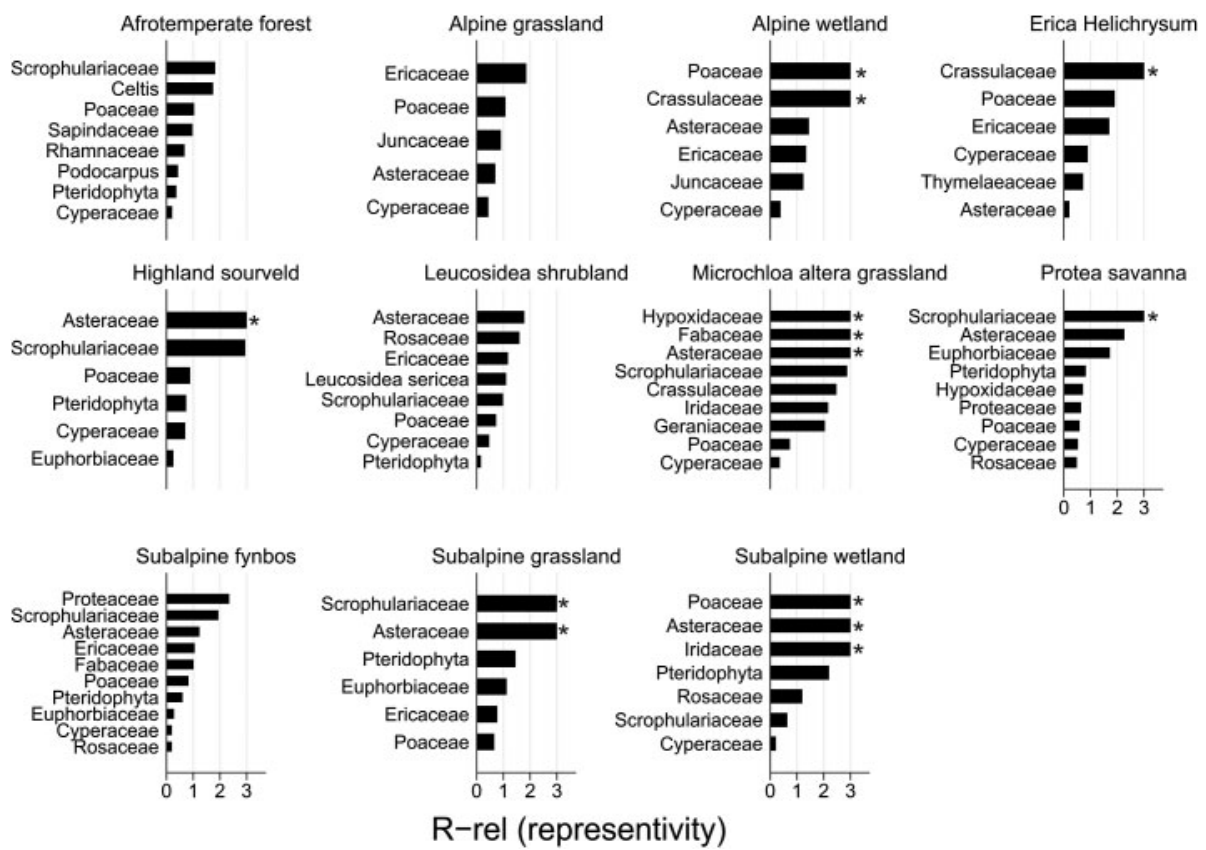

Figure 5. Bar chart showing R-rel (representivity) values of taxa represented in both pollen and vegetation. Asterisks indicate that the R-rel values were too high to show on the figure; For the alpine wetland Crassulaceae $=4.05$, Poaceae = 3.35; for Erica Helichrysum Crassulaceae = 3.35; For Highland sourveld Asteraceae = 3.32; For M. altera grassland Hypoxidaceae $=5.06$, Asteraceae $=4.43$, Fabaceae $=3.52$, for Prote savanna Scrophulariaceae $=3.60$; for subalpine grassland Scrophulariaceae $=5.78$, Asteraceae $=3.07$; for subalpine wetland Asteraceae $=8.09$,

Poaceae $=3.99$. For alpine grassland, alpine wetland, and Erica Helichrysum belt, pollen data are derived from surface soil samples rather than traps.

unrepresented in the pollen assemblage. For the Erica Helichrysum shrubland, this included Santalaceae (Thesium). In the alpine wetland community, all recorded vegetation types were represented in the pollen spectra, at least at family level. Afrotemperate forest appears to have the largest number of 'silent taxa', including Ilex mitis, Gesneriaceae (Streptocarpus), Impatiens, Apiaceae (Conium, Sanicula) and Vitaceae (Rhoicissus). In the L. sericea shrubland, such taxa included Sterculiaceae (Hermannia), Apiaceae (Allipedia), Malvaceae (Hibiscus), and Melianthaceae (Melianthus). Orchidaceae (Disa) pollen was absent from the M. altera grassland despite being recorded in the vegetation plots. In the subalpine fynbos, Gunnera perpensa, Melianthaceae (Melianthus), Olea and Primulaceae (Lysimachia) were absent from the pollen spectra, however, were recorded in the surrounding vegetation. Apiaceae (Allepidea) pollen was similarly absent from the subalpine grassland. Illecebracaceae (Silene) pollen was palynologically silent in both the subalpine grassland and wetland communities. Finally, Valerianaceae (Valeriana) pollen was recorded from the highland sourveld community but absent from the pollen spectra. In the Protea savanna, all plant taxa present were recorded in the pollen traps.

\subsubsection{Multivariate analysis}

The nMDS ordination plot depicts the distribution of the samples relative to vegetation community groupings (Figure 6). The ordination shows discrete clustering of samples within vegetation 


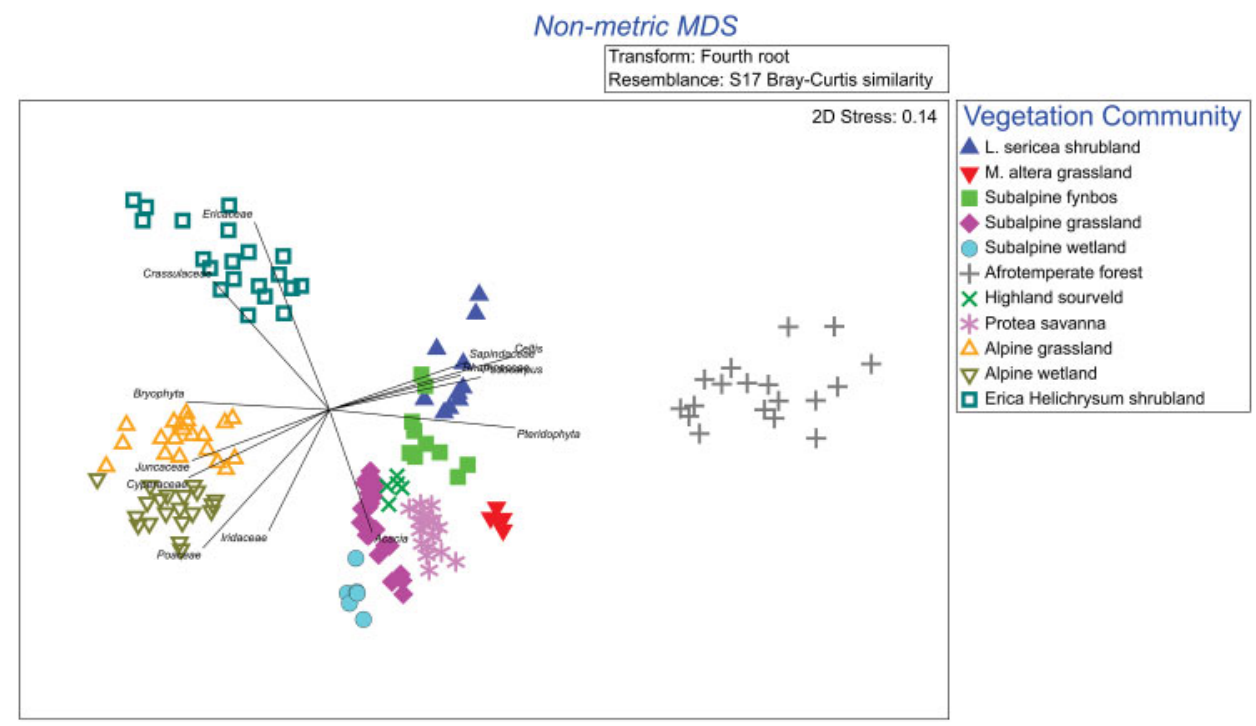

Figure 6. Non-metric multidimensional scaling (nMDS) plot of pollen assemblage data, grouped by vegetation community.

communities, with Afrotemperate forest and Erica Helichrysum shrubland being the most distinctive. Overall, the alpine communities are clearly distinct from the other vegetation belts, illustrating the importance of altitude. The alpine grassland and alpine wetland communities cluster fairly closely together, albeit with no direct overlap. The L. sericea shrubland and subalpine fynbos show some degree of overlap. Subalpine grassland, subalpine wetland, subalpine fynbos, highland sourveld and Protea savanna cluster fairly closely together, but with very limited direct overlap of ordination space.

\subsection{DISCUSSION}

\subsubsection{Modern pollen-vegetation relationships}

The results provide an indication of the relative uniformity of each vegetation community. Furthermore, they allow us to assess whether these vegetation communities can be qualitatively distinguished by their modern pollen assemblages. Here we evaluate whether there is a distinctive pollen signal or are distinctive 'indicator' taxa that can be used to differentiate each community.

Overall, we find that the grassland vegetation communities are relatively difficult to be separated by their pollen assemblage, which can be attributed to the limited taxonomic resolution achievable in identifying grass pollen types (i.e. family level). This is supported by the diversity data, which show that the grassland pollen assemblages consistently underrepresent the diversity of their parent vegetation, when compared with other communities. One exception to this is the alpine grassland community, which the nMDS picks out as a separate cluster from other grassland types. 
The alpine vegetation communities were easily distinguished from communities in other vegetation belts using nMDS. A combination of bryophytes and Crassulaceae (likely from the common Crassula setulosa or possibly the less common Crassula natans) in the pollen assemblage appears to be relatively characteristic of the alpine communities, in particular within the alpine wetland. The alpine wetland community was rather similar to the alpine grassland, with the only differences being a higher frequencies of bryophytes and Juncaceae (Juncus or Lezula), and the presence of Umbelliferae in the alpine wetland. Umbelliferae pollen appears to be restricted in its presence to the alpine wetland community, and therefore serves as a useful indicator taxon. van Zinderen Bakker (1955) recorded Umbelliferae frequencies of 2-8\% in four wetland surface samples in Lesotho.

Scott (1982b) associates the Umbelliferae with damp conditions, however its source at Cathedral Peak is unknown as no members of the Umbelliferae family were recorded in the vegetation. Similar to the situation in the alpine belt, the subalpine wetland and subalpine grassland communities showed a high degree of overlap, with differences being higher Cyperaceae and Pteridophyta in the former, and higher Scrophulariaceae (Selago, Zaluziantskya, Diascia, Manulea, Nemesia, Hebenstretia, Sopubia, Sutera) and Ericaceae (Erica spp.) in the latter.

The Erica Helichrysum shrubland is distinctive in the pollen diagram and the nMDS for consistent, and sometimes relatively high, frequencies of Thymelaeaceae (Passerina montana or Gnidia polystachya), and dominated by high representation of Ericaceae, occasionally exceeding $80 \%$ abundance. In contrast, subalpine fynbos is dominated by a mix of Proteaceae (Protea subvestita), Ericaceae (Erica spp.) and Poaceae, with Rosaceae (Cliffortia or Alchemilla) and Scrophulariaceae (Bowkeria or Halleria) consistently recorded.

The $L$. sericea shrubland has a distinctive pollen signature, with pollen of the shrub $L$. sericea dominating the assemblage (40-60\%), and relatively low Poaceae and Asteraceae frequencies compared with other communities. In the nMDS, however, this community showed a slight overlap with the subalpine fynbos community. Ericaceae is prominent in L. sericea shrubland, as are the Pteridophyta.

The Afrotemperate forest has a highly unique pollen signature, clearly observed in the nMDS, with relatively high arboreal pollen frequencies including Celtis (10-45\%) and Podocarpus $(10-40 \%)$. Sapindaceae pollen, probably from the tree Allophylus melanocarpus, is a good indicator for this community. The Protea savanna community can be distinguished by high Proteaceae pollen frequencies $(20-50 \%)$. Although subalpine fynbos records high Proteaceae, the Protea savanna assemblage can be separated by a lack of Ericaceae pollen, and the two are clearly separated in the nMDS.

The above comparison highlights the challenges of pollen analytical research in a grass dominated environment, and the need for additional supporting proxies such as grass phytoliths to detect palaeovegetation change (e.g. Alexandre et al. 1997). With the potential for $\mathrm{C}_{3} / \mathrm{C}_{4}$ grass species migration with climate change along a clear altitudinal gradient (e.g. Roberts et al. 2013) it could be of some value to attempt to quantitatively distinguish $\mathrm{C}_{3}$ from $\mathrm{C}_{4}$ vegetation. Despite these challenges, the nMDS was able to clearly separate almost all vegetation communities sampled, with limited overlap between samples from different communities.

Those communities with a significant tree component i.e. Afrotemperate forest, Protea savanna and $L$. sericea shrubland, are more easily distinguished by their pollen assemblage. The Erica Helichrysum shrubland and subalpine fynbos, could be distinguished by their dominant fynbos elements, although the latter overlapped with L. sericea in the nMDS. The two wetland communities displayed a strong degree of overlap with the surrounding grassland vegetation, but with some distinctive taxa. The presence of less abundant but nevertheless useful aquatic and 'damp habitat' indicators (sensu Scott 1982b) such as Dipsacaceae (Scabiosa drakensbergensis) and Gunneraceae (Gunnera perpensa) may assist in distinguishing wetland pollen communities. In the subalpine wetland community, Cyperaceae and Pteridophyta were the only 
pollen taxa to record higher abundances than in the surrounding subalpine grassland community. The reality is that fossil pollen preserving archives in these summer rainfall mountain environments tend to be restricted to wetland sediments (e.g. Fitchett et al. 2016 2017, Lodder et al. 2018, Neumann et al. 2014, Norström et al. 2009), thus the fossil pollen signal is usually overrepresented by local wetland taxa, usually excluded from the pollen sum. In the Cathedral Peak area, wetlands representing potential fossil pollen archives are present across a range of altitudes (e.g. Finch et al. 2021; Lodder et al. 2018), from the montane to subalpine to alpine (e.g., this study), although the depth and organic content of these sites is variable.

\subsubsection{Representivity of taxa}

The modern pollen-vegetation comparison allows for some general recommendations regarding interpretation of key taxa based on their relative representivity in the pollen assemblage. These are compared with existing information in the available literature.

Podocarpus - Podocarpus pollen is an important arboreal pollen type in southern African pollen records, and also constitutes an key component of Afromontane vegetation in across Subsaharan Africa (Gajewski et al. 2002; Verlhac et al. 2018; Vincens et al. 2006). Previous studies designate Podocarpus as a very well dispersed anemophilous pollen type (Hamilton 1972), that tends to be overrepresented within the pollen signal (Marchant and Taylor 2000; Schüler et al. 2014). In terms of dispersal, a West African biome-scale study (Verlhac et al. 2018) found Podocarpus pollen distribution to be similar to that of the parent plant, and identified this taxon as a good indicator of modern vegetation. Coetzee (1967) developed a guideline for interpreting Podocarpus pollen frequencies with 10-20\% indicating close proximity of the parent vegetation, and frequencies exceeding 20\% indicative of local presence of Podocarpus forest. Schüler et al. (2014) commented that such overrepresented taxa are 'probably significantly less important components of the surrounding vegetation than indicated by the modern pollen-rain' (Schüler et al. 2014, p. 710). In the Cathedral Peak area, Podocarpus pollen is likely derived predominantly from Podocarpus latifolius, and to a lesser degree from Afrocarpus (formerly Podocarpus) falcatus and Podocarpus henkelii (Killick 1963). Interestingly, our data suggest that Podocarpus pollen is underrepresented relative to the vegetation cover in the Afrotemperate forest community $(\mathrm{R}-\mathrm{rel}=0.4)$, and indeed, with the exception of the M. altera grassland, Podocarpus pollen does not appear to be represented outside of the forest community. This is surprising given the prevalence of small Podocarpus forest patches which form a mosaic within the grassland community (Adie et al. 2017; Figure 1b)). The underrepresentation of Podocarpus within the forest community could be explained by (i) high pollen production by other taxa e.g. Celtis; and/or (ii) the size and complexity of the Afromontane forest community, which appears to be characterised by a heterogeneous pollen signal, with Celtis dominant in some areas and Podocarpus in others. Averaging Podocarpus abundance for both the pollen traps and the parent vegetation across such a heterogeneous community may explain these anomalous results.

Celtis - as with Podocarpus, Celtis pollen is restricted to the Afrotemperate forest community, with the exception of the nearby $M$. altera community $(<300 \mathrm{~m}$ upward of the forest boundary). Within the forest community, Celtis pollen is overrepresented (R-rel =1.7), aligning with previous studies (e.g. Marchant and Taylor 2000), with Celtis being a very well dispersed taxon (Hamilton 1972; Verlhac et al. 2018). Previous studies found Celtis to be abundant pollen producers, present outside of the parent vegetation distribution (Watrin et al. 2007). Interestingly, studies from east and west Africa (e.g., Livingstone 1967; Verlhac et al. 2018) have shown Celtis to be characteristic of lower altitudes than Podocarpus, which is not the case in southern Africa.

Ilex mitis - it was found to be 'palynologically silent' in the Afrotemperate forest community. As a highly distinctive pollen type, this is unlikely to have been missed during analysis. Hamilton (1972) commented that I. mitis has low to poor pollen dispersal capacity, while Marchant and 
Taylor (2000) concluded that Ilex mitis pollen was representative of the density of the parent vegetation.

Cyperaceae - A surprising outcome of this study is that Cyperaceae pollen was found to be underrepresented in both wetland communities, with frequencies consistently below $20 \%$. Cyperaceae pollen often dominates fossil pollen spectra due to the local nature of the taxon. Scott (1982b) and van Zinderen Bakker (1955) found Cyperaceae to be a dominant pollen taxon in modern surface samples, with high frequencies recorded. Lodder et al. (2018) investigated a 5000-yr sediment core retrieved from the subalpine wetland community at Cathedral Peak (Catchment VI), and recorded Cyperaceae abundance of $40-90 \%$ in the fossil assemblages, yet in the current study the modern pollen abundance for the same site remained $<20 \%$ for the two year sampling period. The apparent underrepresentation of Cyperaceae pollen in the current study might be attributed to pollen trap height ( $1 \mathrm{~m}$ from the ground), above the parent vegetation, whereas the other modern sampling campaigns used surface samples. This inference is supported by relatively higher representation of Cyperaceae pollen in surface soil samples as compared with traps in the subalpine wetland (17\% vs. 9\%) (Hill 1992). In a comparison of surface and trap data from the Winterberg, Meadows and Meadows (1988) also found that sedges were more well represented in the surface samples than in the traps, which may be attributed to trap height. Irrespective of differences in apparent representivity between studies, Cyperaceae are ubiquitous across a range of habitat types and climate zones (e.g. Gajewski et al. 2002), and have limited applicability as a palaeoenvironmental indicator.

Ericaceae - The representivity of Ericaceae pollen varied from representative in the subalpine fynbos $(\mathrm{R}-\mathrm{rel}=1.1)$ and $L$. sericea $(\mathrm{R}-\mathrm{rel}=1.2)$ communities to overrepresented in the Erica Helichrysum shrubland (R-rel = 1.7). Marchant and Taylor (2000) and Schüler et al. (2014) designated Ericaceae pollen as overrepresented, although the dispersal characteristics of the pollen taxon are debated, ranging from poorly dispersed (due to large grain size; Verlhac et al. 2018), to moderately dispersed (Hamilton 1972), and well dispersed (Schüler et al. 2014). Dispersal is one facet of pollen representivity, but so too is pollen production, and to a lesser degree in modern samples, preservation.

Poaceae - The results indicate a wide degree of variability in the representivity of Poaceae pollen between different communities, with few obvious patterns apparent. The two wetland communities showed a high degree of overrepresentation of Poaceae pollen relative to vegetation cover. In the closed vegetation communities, Poaceae pollen varied from representative in the Afrotemperate forest $(\mathrm{R}-\mathrm{rel}=1.0)$ to underrepresented in the $L$. sericea shrubland $(\mathrm{R}-\mathrm{rel}=0.7)$ and Protea savanna (R-rel $=0.6)$. Within open ecosystems and grassland communities, the degree of Poaceae representivity was highly variable. Previous studies have designated Poaceae pollen as a generally well dispersed taxon linked to it's anemophilous pollination syndrome (Hamilton 1972), consequently often overrepresented within the pollen signal.

\subsection{CONCLUSIONS}

The original palynologists' dream was to develop a 'signature' modern pollen assemblage for each distinct vegetation community within the three recorded vegetation belts, viz. montane, subalpine and alpine, in the KwaZulu-Natal Drakensberg. With this achieved, the aim was to correlate, or cross-reference, dated fossil pollen spectra against these modern analogues to infer past vegetation communities, which could then be extended to interpret palaeoenvironments. As with any palaeoreconstruction proxy, the outcome is less straightforward and open to interpretation.

We identified eleven vegetation communities across the three altitudinal belts, undertook a vegetation survey, deployed pollen traps and/or collected surface soil samples. Modern pollen sampling was conducted over two years and influx values were calculated. Overall, a high degree of homogeneity exists both within and between communities with regards to modern pollen, 
although characteristic taxa could be identified for certain communities. Dominant pollen taxa were often over- or underrepresented in comparison with the surrounding vegetation composition and abundance, taking cognisance of the taxonomic resolution. We note and justify these characteristic taxa and suggest reasons why they could prove useful as signature taxa during fossil pollen interpretation. Perhaps unsurprisingly, there appears to be little variation across the various grassland communities, greater opportunity exists to recognise the forest and shrubland types, and to distinguish the communities from different altitudinal vegetation belts, e.g. alpine communities.

The Drakensberg is a region with a high palynological potential, however it is imperative that any palaeoreconstruction be based on a sound understanding of the modern pollen processes. Therefore, contemporary pollen rain-vegetation relationships and modern analogues should be considered and refined. Thus, in conjunction with other palaeoecological proxies and dating methods, one is able to build a clearer picture of past environments in a mountainous region which has a high biodiversity and displays clear altitudinal and latitudinal gradients, imperative to improving our understanding of the past environments in southern Africa.

\section{ACKNOWLEDGEMENTS}

TRH was funded by the Foundation for Research and Development and Rhodes University. Brice Gijsbertsen professionally drafted Figure 1. The staff of Cathedral Peak Forestry and Research Station are thanked for their hospitality, and for allowing the opportunity to work in such tranquil surroundings. Thank you to Colin and Terry Everson, and Martin Hill for assisting with fieldwork. Andrew Steele assisted with data entry. Elodie Heyns-Veale kindly assisted with the multivariate analysis. We thank Henry Lamb and one anonymous reviewer for constructive feedback on the manuscript.

\section{REFERENCES}

Adie, H., Kotze, D.J. and Lawes, M.J., 2017, Small fire refugia in the grassy matrix and the persistence of Afrotemperate forest in the Drakensberg mountains. Scientific Reports, 7, article: 6549, 10.1038/s41598-017-06747-2.

Alexandre, A., Meunier, J.-D, Lezine, A.M., Vincens, A. and Schwartz, D. 1997, Phytoliths: indicators of grassland dynamics during the late Holocene in intertropical Africa. Palaeogeography, Palaeoclimatology, Palaeoecology, 136, pp. 213-229, 10.1016/S0031-0182(97)00089-8.

Barnes, B.V., Zak, D.R., Denton, S.R. and Spurr, S.H. 1998, Forest Ecology, (New York: Wiley).

Berglund, B.E. and Ralska-Jasiewiczowa, M. 1986, Pollen analysis and pollen diagrams. In: Handbook of Holocene Palaeoecology and Palaeohydrology edited by Berglund B.E., pp. 455-484 (Chichester: John Wiley \& Sons).

Bradshaw, R.H.W., 1981, Modern pollen-representation factors for woods in South-East England. Journal of Ecology, 69, pp. 45-70, 10.2307/2259815.

Clarke, K.R. and Gorley, R.N. 2015. PRIMER v7: User Manual / Tutorial (1st edn). Plymouth: PRIMER-E ltd.

Coetzee, J.A. 1967, Pollen analytical studies in East and southern Africa. (Cape Town: Balkema).

Cooremans, B. 1989, Pollen production in central southern Africa. Pollen et Spores, 36, pp. 61-78.

Crowder, A. and Starling, R.N. 1980, Contemporary pollen in the Salmon River Basin, Ontario. Review of Palaeobotany and Palynology, 30, pp. 11-26, 10.1016/0034-6667(80)90003-2.

Davis, M.B. 1963, On the theory of pollen analysis. American Journal of Science, 261, pp. 897-912, 10.2475/ajs.261.10.897. 
Duffin, K.I. and Bunting, J. 2008, Relative pollen productivity and fall speed estimates for southern African savanna taxa. Vegetation History and Archaeobotany, 17, pp. 507-525, 10.1007/s00334-007-0101-2.

Elenga, H., de Namur, C., Vincens, A., Roux, M., and Schwartz, D., 2000, Use of plots to define pollen-vegetation relationships in densely forested ecosystems of Tropical Africa. Review of Palaeobotany and Palynology, 112, 79-96, 10.1016/S0034-6667(00)00036-1.

Faegri, K. and Iversen, J. 1989, Textbook of Pollen Analysis, 4th Edition, (Chichester: John Wiley \& Sons).

Finch, J.M., Hill, T.R., Meadows, M.E., Lodder, J. and Bodmann, L., 2021, Fire and montane vegetation dynamics through successive phases of human occupation in the northern Drakensberg, South Africa. Quaternary International, 10.1016/j.quaint.2021.01.026.

Fitchett, J.M., Grab, S.W., Bamford, M.K. and Mackay, A.W., 2016, A multi-proxy analysis of late Quaternary palaeoenvironments, Sekhokong Range, eastern Lesotho. Journal of Quaternary Science, 31, pp. 788-798, 10.1002/jqs.2902.

Fitchett, J.M., Mackay, A.W., Grab, S.W. and Bamford, M.K. 2017, Holocene climatic variability indicated by a multi-proxy record from southern Africa's highest wetland. The Holocene, 27, pp. $638-650$.

Flenley, J.R. 1973, The use of modern pollen rain samples in the study of the vegetational history of tropical regions. In: Quaternary Plant Ecology, edited by Birks, H.J.B. and West R.G., (Oxford: Blackwell), pp. 131-141.

Gajewski, K., Lézine, A-M., Vincens, A., Delestan, A., Sawada, M. and the African Pollen Database, 2002, Modern climate-vegetation-pollen relations in Africa and adjacent areas. Quaternary Science Reviews, 21, 1611-1631, 10.1016/S0277-3791(01)00152-4.

Gosling, W.D., Mayle, F.E., Tate, N.J. and Killeen, T.J. 2005, Modern pollen-rain characteristics of tall terra firme moist evergreen forest, southern Amazonia. Quaternary Research, 64, pp. 284-297, 10.1016/j.yqres.2005.08.008.

Hamilton, A.C. 1972, The interpretation of pollen diagrams from highland Uganda. Palaeoecology of Africa, 7, pp. 45-149.

Henga-Botsikabobe, K., Ngomanda, A., Oslisly, R., Favier, C., Muller, S.D., and Bremond, L., 2020, Modern pollen-vegetation relationships within tropical marshes of Lopé National Park (Central Gabon). Review of Palaeobotany and Palynology, 275, 10.1016/j.revpalbo. 2020.104168, article: 104168 .

Hicks, S. and Hyvärinen, V., 1986, Sampling modern pollen deposition by means of "Tauber traps": Some considerations. Pollen et Spores, 28, pp. 219-242.

Hill, T.R., 1992, Contemporary pollen spectra from the Natal Drakensberg and their relation to associated vegetation communities. PhD Thesis, Rhodes University, Grahamstown.

Hill, T.R., 1995, Analysis of contemporary pollen rain in South Africa - A review. Transactions of the Royal Society of southern Africa, 50, pp. 27-39, 10.1080/00359199509520327.

Hill, T.R., 1996, Description, classification and ordination of the dominant vegetation communities, Cathedral Peak, KwaZulu Natal Drakensberg. South African Journal of Botany, 62, pp. 263-269, 10.1016/S0254-6299(15)30655-4.

Hill, T.R., Duthie, T.J. and Bunting, M.J. this volume, Relevant source area of pollen and pollen productivity estimates from KwaZulu-Natal Drakensberg, South Africa. Palaeoecology of Africa, 35, chapter: 16, 10.1201/9781003162766-16.

Juggins S., 2007, C2 Version 1.5 Software for ecological and palaeoecological data analysis and visualisation (Newcastle upon Tyne: Newcastle University).

Julier, A.C.M., Jardine, P.E., Adu-Bredud, S., Coea, A.L., Duah-Gyamfid, A., Fraser, W.T., Lomax, B.H., Malhi, Y., Moore, S., Owusu-Afriyied, K. and Gosling, W.D., 2018, The modern pollen-vegetation relationships of a tropical forest-savannah mosaic landscape, Ghana, West Africa. Palynology, 42, pp. 324-338, 10.1080/01916122.2017.1356392. 
Kershaw, K.A. and Looney, J.H.H., 1985, Quantitative and dynamic plant ecology (London: Edward Arnold).

Killick, D.J.B., 1963, An account of the plant ecology of the Cathedral Peak Area of the Natal Drakensberg, Memoirs of the Botanical Society of South Africa, Number 34, (Praetoria: The Government Printer).

Livingstone, D.A., 1967, Postglacial vegetation of the Ruwenzori Mountains in equatorial Africa. Ecological Monographs, 37(1), pp. 25-52, 10.2307/1948481.

Lodder, J., Hill, T.R. and Finch, J.M. 2018, A 5000-yr record of Afromontane vegetation dynamics from the Drakensberg Escarpment, South Africa. Quaternary International, 470, pp. 119-129, 10.1016/j.quaint.2017.08.019.

Marchant, R. and Taylor, D. 2000, Pollen representivity of montane forest taxa in south-western Uganda. New Phytologist, 146, pp. 515-525, 10.1046/j.1469-8137.2000.00662.x.

Meadows, M.E., 2015, Seven decades of Quaternary palynological studies in southern Africa: a historical perspective, Transactions of the Royal Society of South Africa,70(2), pp. 103-108, 10.1080/0035919X.2015.1004139.

Meadows, M.E. and Meadows, K.F., 1988, Late Quaternary vegetation history of the Winterberg Mountains, Eastern Cape, South Africa. South African Journal of Science, 84, pp. 253-259.

Meadows, M.E. and Sugden, J.M., 1990, Late Quaternary vegetation history of the Cederberg, south-western Cape. Palaeoecology of Africa, 21, pp. 269-281.

Meadows, M.E. and Sugden, J.M., 1991a, A vegetation history of the last 14000 years on the Cederberg, south-western Cape Province. South African Journal of Science, 87, pp. 34-43.

Meadows, M.E. and Sugden, J.M., 1991b, The application of multiple discriminant analysis to the reconstruction of the vegetation history of Fynbos, southern Africa. Grana, 30, pp. 325-336, 10.1080/00173139109431987.

Neumann, F.H., Botha, G.A. and Scott, L. 2014, 18,000 years of grassland evolution in the summer rainfall region of South Africa: evidence from Mahwaqa Mountain, KwaZulu-Natal. Vegetation History and Archaeobotany, 23, pp. 665-681, 10.1007/s00334-014-0445-3.

Norström, E., Scott, L., Partridge, T.C., Risberg, J. and Holmgren, K. 2009, Reconstruction of environmental and climatic changes at Braamhoek wetland, eastern escarpment South Africa, during the last 16,000 years with emphasis on the Pleistocene-Holocene transition. Palaeogeography Palaeoclimatology Palaeoecology, 271, pp. 240-258, 10.1016/j.palaeo.2008.10.018.

Roberts, P., Lee-Thorp, J.A., Mitchell, P.J. and Arthur, C., 2013, Stable carbon isotopic evidence for climate change across the Late Pleistocene to early Holocene from Lesotho, southern Africa. Journal of Quaternary Science, 28, 360-369, 10.1002/jqs.2624.

Schüler, L., Hemp, A. and Behling, H., 2014, Relationship between vegetation and modern pollen-rain along an elevational gradient on Kilimanjaro, Tanzania. The Holocene, 24, pp. 702 713, 10.1177/0959683614526939.

Scott, L., 1982a, A late Quaternary pollen record from the Transvaal bushveld, South Africa. Quaternary Research, 17, pp. 339-170, 10.1016/0033-5894(82)90028-X.

Scott, L., 1982b, Late Quaternary fossil pollen grains from the Transvaal, South Africa. Review of Palaeobotany and Palynology, 36, pp. 241-18, 10.1016/0034-6667(82)90022-7.

Scott, L. and Cooremans, B., 1992, Pollen in recent Procavia (hyrax), Petromus (dassie rat) and bird dung in South Africa. Journal of Biogeography, 19, pp. 205-215, 10.2307/2845506.

Scott, L., Cooremans, B. and Maud, R.R., 1992, Preliminary palynological evaluation of the Port Durnford formation at Port Durnford, Natal coast, South Africa. South African Journal of Science, 88, pp. 470-474.

Sobol, M.K., Scott, L. and Finkelstein, S.A., 2019, Reconstructing past biomes states using machine learning and modern pollen assemblages: A case study from Southern Africa. Quaternary Science Reviews, 212, pp. 1-17, 10.1016/j.quascirev.2019.03.027. 
Sugden, J.M., 1990, Late Quaternary palaeoecology of the central and marginal Uplands of the Karoo, South Africa. PhD thesis, University of Cape Town.

Sugden, J.M. and Meadows, M.E., 1989, The use of multiple discriminant analysis in reconstructing recent vegetation changes on the Nuweveldberg, South Africa. Review of Palaeobotany and Palynology, 60, pp. 131-147, 10.1016/0034-6667(89)90073-0.

van Zinderen Bakker, E.M., 1950, Palynology in Africa. First report, covering the year 1950 . Palaeoecology of Africa, 1, pp. 1-4.

van Zinderen Bakker, E.M., 1951, Palynology in Africa. Second report, covering the year 1951. Palaeoecology of Africa, 1, pp. 5-8.

van Zinderen Bakker, E.M., 1955, A preliminary survey of the peat bogs of the Alpine belt of northern Basotholand. Acta Geographica, 14, pp. 413-422.

Verlhac, L., Izumi, K., Lézine, A-M., Lemonier, K., Buchet, G., Achoundong, G., and Tchiengué, B. 2018. Altitudinal distribution of pollen, plants and biomes in the Cameroon Highlands. Review of Palaeobotany and Palynology, 259, pp. 21-28, 10.1016/j.revpalbo.2018.09.011.

Vincens, A., Bremond, L., Brewer, S., Buchet, G. and Dussouillez, P. 2006. Modern pollen-based biome reconstructions in East Africa expanded to southern Tanzania. Review of Palaeobotany and Palynology, 140, pp. 187-212, 10.1016/j.revpalbo.2006.04.003.

Watrin, J., Lézine, A-M., Gajewski, K. and Vincens, A. 2007, Pollen-plant-climate relationships in sub-Saharan Africa. Journal of Biogeography, 34, pp. 489-499, 10.1111/j.13652699.2006.01626.x. 